\title{
Acute Lymphoblastic Leukemia after previously treated, relapsed Chronic Lymphocytic Leukemia: A Case Report
}

\author{
ELENA ANDRUS, ANCA NICOLESCU, H. BUMBEA, ANA-MARIA VLĂDĂREANU
}

Department of Hematology, Emergency University Hospital, Bucharest

\begin{abstract}
We present the case of a 71-year-old woman diagnosed with chronic lymphocytic leukemia who received multiple chemotherapeutic lines and evolved to acute lymphoblastic leukemia. The patient was Rai stage 0 at the time of the diagnosis and was monitored for almost 9 years. After that, the disease progressed and the patient began chemotherapy (fludarabine/cyclophosphamide combination), obtained complete remission and relapsed one year later after finishing treatment. She received multiple therapeutic regimens, accompanied by multiple infectious complications. After 8 years of evolution since she started chemotherapy, bone marrow aspirate and immunophenotyping revealed acute lymphoblastic leukemia. The occurrence of acute leukemia in CLL is rare and may arise from the same clone; however, most cases appear after patients have received chemotherapy, suggesting that they are therapy-related.
\end{abstract}

Key words: chronic lymphocytic leukemia, acute lymphoblastic leukemia, second malignancy, Richter transformation.

\section{INTRODUCTION}

Chronic lymphocytic leukemia is the most common form of leukemia found in pathology of the adult (about $22.6 \%$ of all leukemias) [1-3]. CLL is a slow kinetics disease, where clonal proliferation and accumulation of tumoral lymphocytes (with mature morphologic appearance, but immature functionally) is done progressively, generating clinical manifestations more or less troublesome. Still, individual prognosis of a CLL patient remains highly variable: from indolent forms of the disease, without reducing life expectancy (in most cases) to rapidly progressive disease and limited response to treatment, overall survival rate ranging from a few months to decades [4]. Due to prolonged immunosuppression caused both by the disease itself and by chemotherapy, a second malignancy can occur in the evolution of CLL $[5,6]$. Transformation in acute leukemia is very rare $(<1 \%$ of cases), most cases found in patients treated with alkylating agents in combination with nucleoside analogues [7-9]. We present the case of a patient with CLL who evolved to acute lymphoblastic leukemia after receiving multiple therapeutic lines.

\section{CASE REPORT}

We present the case of a 71-year-old woman with associated pathology (chronic atrial fibrillation, arterial hypertension) who was incidentally diagnosed with chronic lymphocytic leukemia (mild leukocytosis with lymphocytosis on routine blood count) in 1997, stage Rai 0. The patient was monitored periodically every 3 months, using physical examination and blood count, for almost 9 years, while she had a stable clinical course. In 2006 CBC reveals incresead leukocytosis with lymphocytosis (WBC $\sim 40.000 / \mathrm{mm}^{3}, 80 \%$ lymphocytes, confirmed by peripheral blood smear - Figure 1a) and the patient accuses night sweats. She starts treatment with chlorambucil, with modest hematological response. In April 2006 we detect progression of the disease: enlargement of lymph nodes, with $2.5 \mathrm{~cm}$ maximum diameter, splenomegaly, mild enlargement of the liver; CBC with WBC $55.000 / \mathrm{mm}^{3}$ with lymphocytosis and general sypmtoms also present (fatigue, night sweats, weight loss). Surrogate prognostic markers CD38 and ZAP-70 protein were both positive (Figure 3 a,b,c,). The patient starts chemotherapy, flud- 
arabine/cyclophosphamide combination (Rituximab not available at that time) and achieves complete response after 8 cycles of treatment. In June 2007 she relapsed, one year later after achieving CR. We reinitiate chemotherapy with the same protocol (FC), but after 5 cycles the patient develops Pneumocystis carinii pneumonia, hardly responsive to specific treatment. She continues chemotherapy until October 2008, when we certify CR, which lasted till 2012. In January 2012 she relapses again. FISH analysis did not identify any abnormalities. The patient begins treatment with alemtuzumab. After finishing alemtuzumab protocol the patient remains with persistent pancytopenia, severe neutropenia despite using granulocyte growth factors, moderate anemia for which she required erythropoietin and blood transfusions and persistent thrombocytopenia. For almost 1 year the patient suffered multiple infectious complications (pneumonias, acute tracheobronchitis - repeated episodes), but hematologically with stable disease, without specific treatment. In 2013 she develops HBV infection and receives antiviral therapy with Lamivudin (Entecavir not available), with undetectable viremia. In August 2014 the patient was admitted to our department with malaise, fever, cough, dyspnoea, loss of appetite, weight loss over 10 kilograms, cachexia. On clinical examination she had intense pallor, purpura and petechiae on the legs, spontaneous bruising on the extremities, bilateral cervical and axillar lymph nodes up to $3 \mathrm{~cm}$ diameter, inguinal lymphadenopathies up to $2.5 \mathrm{~cm}$ diameter, pulmonary - disseminated bronchial rales, atrial fibrillation rhythm, hepatosplenomegaly. CBC revealed severe anemia $(\mathrm{Hb} \sim 4.9 \mathrm{~g} / \mathrm{dl})$, severe thrombocytopenia (PLT $\sim 9.000 / \mathrm{mm}^{3}$ ) and leucopenia (WBC $\sim 2.900 / \mathrm{mm}^{3}$ ). Peripheral blood smear showed $80 \%$ lymphocytes, $1 \%$ blast cells (Figure $1 \mathrm{~b}, \mathrm{c}$ ) and nuclear shadows. Bone marrow aspirate examination showed $46 \%$ immature cells medium size blasts, with fine chromatin nucleus, nucleoli, quantitatively reduced basophilic cytoplasm and $45 \%$ small lymphocytes (Figure 2 a,b,c,d). Immunophenotyping profile of blast cells (Figure 4 a,b) was: CD34+ CD5- CD10+ CD19+ CD20cCD79a + cTdT+ sIg - cy Ig - , which outlines the diagnosis of acute lymphoblastic leukemia (common ALL according to EGIL classification (European Group for the Immunological Characterization of Leukemias)) [10]. Unfortunately, cytogenetic analysis and molecular evaluation were not performed. A CT scan was performed, which revealed multiple lymphadenopathies, hepatosplenomegaly and foci of bronchopneumonia. Due to associated comorbidities, advanced age, poor performance status, severe pancytopenia and active bronchopneumonia, the patient had no indication for chemotherapy (UKALL protocol for ALL) and received only supportive treatment: blood transfusions, platelet transfusions, antibiotics, antiviral treatment and supportive care for vital functions. Clinical course was extremely aggressive. She rapidly developed sepsis and multiple organ failure leading to death, on behalf of severe neutropenia and immunosuppression background given by chemotherapy used for treating relapsed CLL.
A

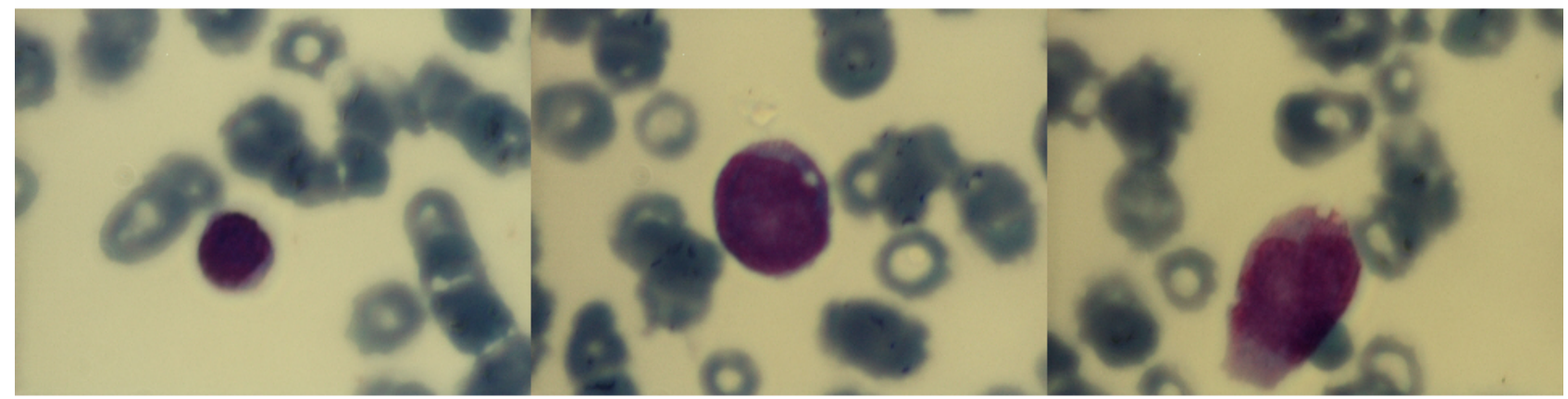

Fig. 1. (a): Peripheral blood smear, May-Grunwald-Giemsa stained, OM $100 \mathrm{X}$ : small size lymphocyte, nucleus with chromatin condensation, slightly basophilic reduced cytoplasm. (b): Peripheral blood smear, May-Grunwald-Giemsa stained, OM 100 X: medium size blast, fine chromatin nucleus, nucleoli, basophilic, quantitatively reduced cytoplasm.

(c): Peripheral blood smear, May-Grunwald-Giemsa stained, OM 100 X: blast with incised nucleus. 
A

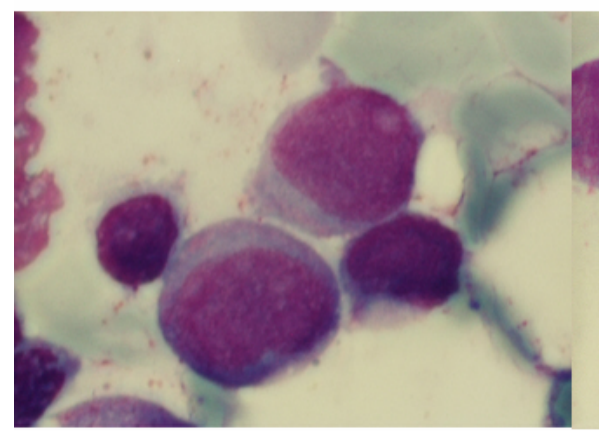

B

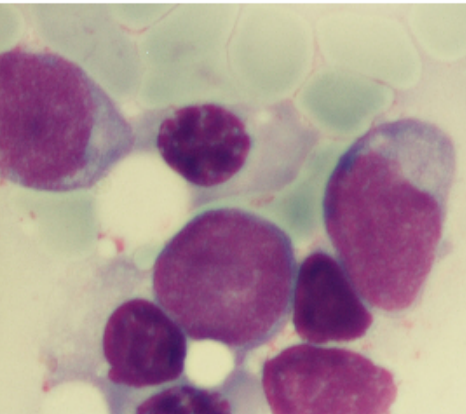

$\mathrm{C}$

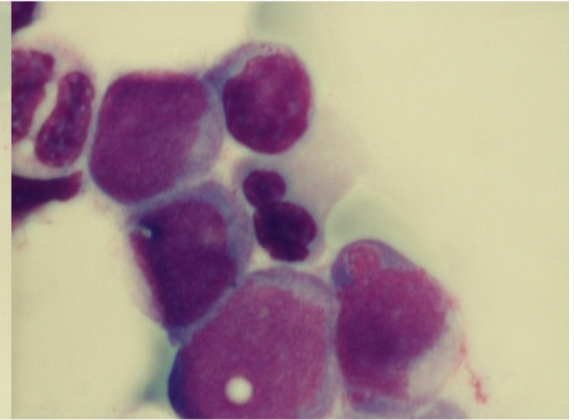

Fig. 2. Bone marrow aspirate, May-Grunwald-Giemsa stained, OM 100 X. (a): 2 medium size blasts, fine chromatin nucleus with nucleoli, quantitatively reduced basophilic cytoplasm, without granules, and 2 small lymphocytes, condensed chromatin nucleus, low basophilic cytoplasm. (b): 3 blasts, 3 erythroblasts, lymphocyte, nuclear shadows. (c): 4 blasts, lymphocyte, segmented neutrophil, binucleated erythroblast.

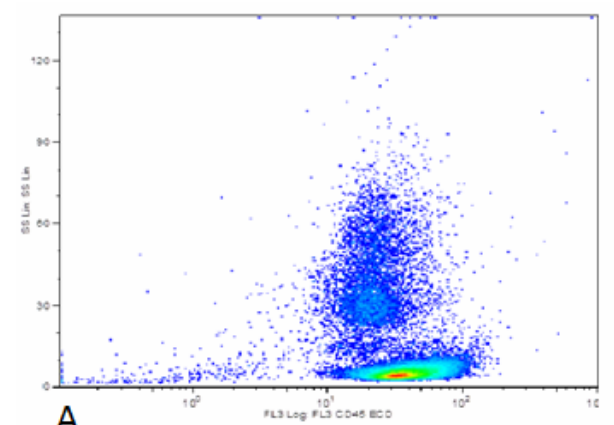

A

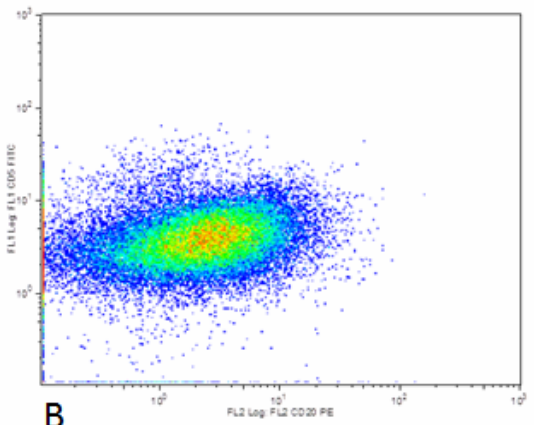

B

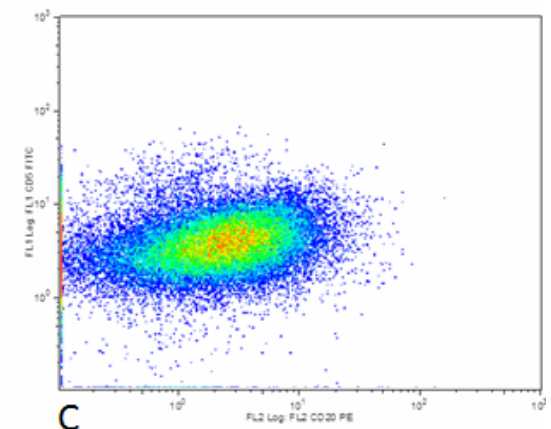

C
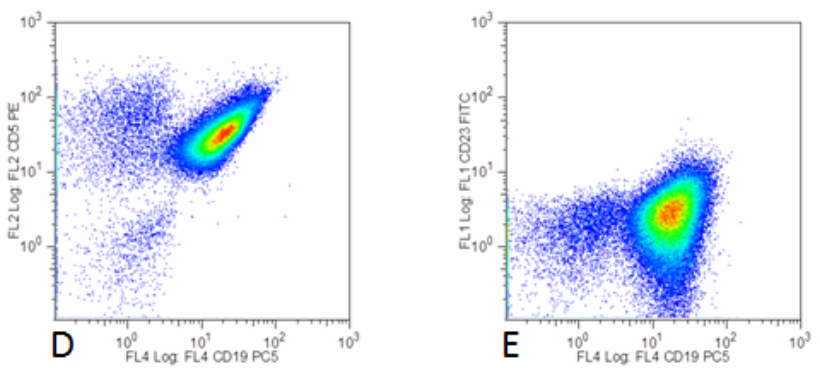

Fig. 3. Chronic Lymphocytic Leukemia - flowcytometry histograms. (a): Dot-plot figure representing immunophenotyping of peripheral blood, FC500 Cytomics cytometer. There could be observed lymphocytes CD45++ SSC low in high percentage.

(b): Dot-plot figure representing immunophenotyping of peripheral blood, FC500 Cytomics cytometer. B Lymphocytes

CD5+CD20+. (c): Dot-plot figure representing immunophenotyping of peripheral blood, FC500 Cytomics cytometer.

B Lymphocytes CD20+CD38+. (d): Dot-plot figure representing immunophenotyping of peripheral blood, FC500 Cytomics cytometer. B Lymphocytes CD5+ CD19+. (e): Dot-plot figure representing immunophenotyping of peripheral blood,

FC500 Cytomics cytometer. B Lymphocytes CD19+ CD23+.
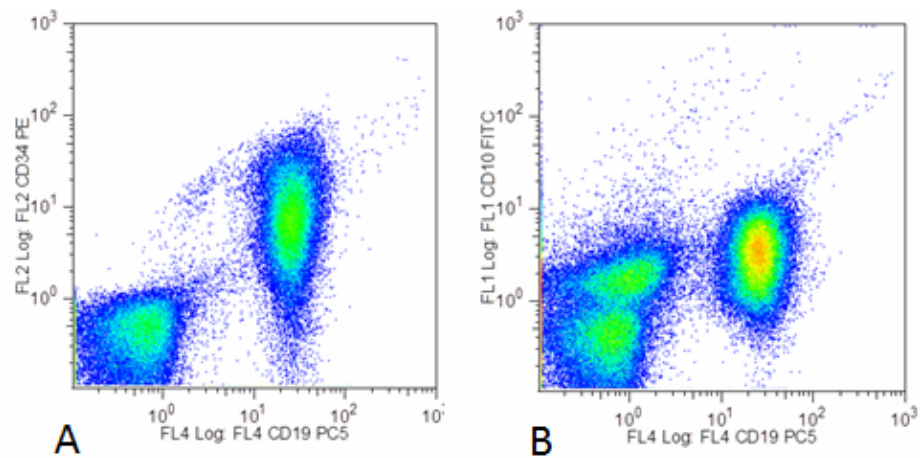

Fig. 4 (a, b). B Cell Acute Lymphoblastic Leukemia - flowcytometry histograms. 


\section{DISCUSSION}

Acute leukemia occurs in $<1 \%$ cases of CLL. The appearance of ALL has been described in several cases; this rare "transformation" is considered by some authors just a coincidence, knowing the fact that blastic transformation does not occur in CLL. Acute myeloblastic leukemia occurs more frequently, secondary to prolonged treatment with alkylating agents. Some studies support the idea that myelodysplasia and AML may arise from the same clone [6]. The risk of developing AML after treatment with alkylating agents or nucleoside analogues alone appears to be very low, although the risk increases if both are given together [11]. In our case, the occurrence of ALL after relapsed, previously treated CLL, seems to be due more to prolonged immunosuppression, caused by the disease itself, advanced age and associated comorbidities, rather than chemotherapy. However, she received both alkylating agents and nucleoside analogues, increasing the risk for a second malignancy in her clinical course. The prognosis of ALL secondary to relapsed CLL in adults is poor, with very low response to chemotherapy, increased haematological toxicity and short survival.

\section{CONCLUSION}

CLL cells derive from competent B lymphocytes selected by clonal expansion and possibly transformed by repeated antigenic stimulation and immune response to self or external antigens. Leukemic cells have a distinct phenotype, typical lack of response to exogenous stimuli, absence of measurable proliferation and deficiency of apoptosis. It is well known that defects in apoptosis control frequently occur in malignant diseases. Progressive accumulation of leukemic cells is due to the fact that they have a survival advantage compared to normal B lymphocytes (leukemic cells survive several months, while normal lymphocytes only a few days). At the same time, defects in apoptosis contribute to chemoresistance, and so to the incurability of the disease. Optimal management of elderly patients with CLL requires knowledge of performance status of the patient and risk assessment. Prognostic factors are less conclusive in the elderly, due to differences in CLL biology, decreased life expectancy and associated comorbidities, which significantly reduce the benefit of treatment. Predictors time to initiation of treatment in all age groups are represented by: CD38, ZAP-70, IgVH status, FISH technique. Second neoplasia may occur in the evolution of CLL only in rare cases and seems to be therapy related, on a prolonged immunosuppression background.

\begin{abstract}
Prezentăm cazul unei femei în vârstă de 71 de ani diagnosticată cu leucemie limfocitară cronică, care a primit multiple regimuri chimioterapice şi a evoluat în leucemie limfoblastică acută. Pacienta era în stadiul Rai 0 de boală la momentul diagnosticului şi a fost monitorizată timp de aproape 9 ani. După această perioadă, boala a progresat, pacienta a primit tratament chimioterapic (cure tip $F C$ fludarabină / ciclofosfamidă), a obținut remisiunea completă, dar a recăzut după un an de la terminarea tratamentului. S-au aplicat mai multe linii terapeutice, însoțite însă de multiple complicații infecțioase. După 8 ani de evoluție de la inceperea chimioterapiei, examenul aspiratulului medular şi imunofenotiparea au evidențiat leucemie limfoblastică acută. Transformarea în leucemie acută este rar intâlnită în LLC şi poate rezulta din aceeaşi clonă; cu toate acestea, cele mai multe cazuri apar la pacienții care au primit chimioterapie, sugerând că sunt induse de tratamentul citostatic.
\end{abstract}

Corresponding author: Prof. Dr. Ana Maria Vlădăreanu,

Department of Hematology, Emergency University Hospital, Bucharest,

E-mail: anamariavladareanu@yahoo.com

The authors declare no conflict of interest. 


\section{REFERENCES}

1. DIEHL LF, KARNELL LH, MENCK HR. The National Cancer Data Base report on age, gender, treatment, and outcomes of patients with chronic lymphocytic leukemia. Cancer 1999; 86:2684-2692.

2. SGAMBATI MT, LINET MS, DEVESA SS. Chronic lymphocytic leukemia: epidemiological, familial, and genetic aspects. In: Cheson BD, ed. Chronic lymphoid leukemias, $2^{\text {nd }}$ ed. New York: Marcel Dekker, 2001:33-62.

3. ZENT CS, KYASA MJ, EVANS R, et al. Chronic lymphocytic leukemia incidence is substantially higher than estimated from tumor registry data. Cancer 2001; 92:1325-1330.

4. BINET JL, AUQUIER A, DIGIERO G, et al. A new prognostic classification of chronic lymphocytic leukemia derived from a multivariate survival analysis. Cancer. 1981; 48:198-206.

5. KYASA MJ, HAZLETT L, PARRISH RS, et al. Veterans with CLL/SLL have a markedly increased rate of second malignancy, which is the most common cause of death. Leuk Lymphoma 2004; 45:507-513.

6. ROBAK T. Second malignancies and Richter syndrome in patients with chronic lymphocytic leukemia. Hematology 2004; 9:387-400.

7. ZARRABI MH, GRUNWALK HW, ROSNER F. Chronic lymphocytic leukemia terminating in acute leukemia. Arch Intern Med 1977; 137:1059-1064.

8. ROBERTSON LE, ESTEY E, KANTARJIAN H, et al. Therapy related leukemia and myelodysplastic syndrome in chronic lymphocytic leukemia. Leukemia 1997; 8:2047-2051.

9. MORRISON VA, RAI KR, PETERSON BL, et al. Therapy-related myeloid leukemias are observed in patients with chronic lymphocytic leukemia after treatment with fludarabine and chlorambucil: results of an intergroup study, cancer and leukemia group B 9011. J Clin Oncol 2002; 20:3878-3884.

10. BENE MC, CASTOLDI G, ORFAO A, et al. Proposal for the immunological classification of acute leukemias.Leukemia.1995; 10:1783-6.

11. FLINN IW, NEUBERG DS, GRVER MR, et al. Phase III trial of fludarabine and cyclophosphamide compared with fludarabine for patients with previously untreated chronic lymphocytic leukemia: US Intergroup Trial E2997. J Clin Oncol 2007; 25:793-798. 